\title{
Mechanism of action of functional lipids and metabolites for patients with chronic kidney disease
}

\author{
Shruti Vig, Venkata S. Sabbisetti and Amrendra K. Ajay
}

Renal Division, Brigham and Women's Hospital, Harvard Medical School, Boston, MA, 02115, USA

Corresponding author: Amrendra K. Ajay, Ph.D., Renal Division, Brigham and Women's Hospital, Harvard Medical School, Boston, MA, 02115, USA

Submission Date: October $30^{\text {th }}$, 2018. Acceptance Date: June $26^{\text {th }}$, 2019. Publication Date: June 30, 2019.

Citation: Vig S., Sabbisetti V.S., and Ajay A.K. Functional lipids and other functional metabolites intake for patients with chronic kidney disease: their target and mechanism of action. Functional Foods in Health and Disease 2019; 9(6): 412-429. DOI: https://doi.org/10.31989/ffhd.v9i5.578

\section{ABSTRACT}

Chronic kidney disease (CKD) is a general term for a diverse variety of causes affecting kidney structure and function. The term "chronic" is because the damage to the kidneys happens slowly over a long period. Damaged kidneys cannot filter extra water and wastes out of blood as compared to the healthy kidneys. The disease prognosis and control are categorized based on disease severity, which is evaluated by glomerular filtration rate (GFR) and albuminuria, and clinical diagnosis. Progression of CKD thus causes wastes to build up in the body and is associated with many severe complications, including increased incidence of cardiovascular disease, hyperlipidemia, anemia, and metabolic bone disease.

Forty percent of CKD is a result of complications associated with diabetes. Patients with diabetes are suggested to intake components that have reduced amount of carbohydrates and increased amount of proteins. Patients with CKD are suggested to intake a low protein diet. Thus, there is a fine need for CKD patients to understand the food constituents and functional components. Given the intricacies of the renal diet and the difficulties faced by patients due to conflicting recommendations and complexities faced in understanding processed food labels, there is a lot of emphasis in the present world to change the focus in CKD away from what not to eat to the concept of good nutrition as positive medicine or therapy for kidney patients.

Specifically, there has been a surge in consumer interest on the beneficial role of specific foods with physiologically-active food components, so-called functional foods benefitting CKD. In the past century, increased attention to lifestyle and healthy diets has led to an increase in demand for functional foods.

Thus, this review will discuss the key components that have been investigated in vivo using rodent models, some clinical trials and studies for being identified as a 'nutraceuticals' for patients with CKD.

Keywords: Chronic kidney disease, Functional food, Conjugated Linoleic acid, LDL, HDL, Protein diet, Omega fatty acids, L-Carnitine. 


\section{INTRODUCTION}

Chronic kidney disease (CKD) is a serious and universal health problem that its occurrence is increasing rapidly with more than one million people with CKD dying every year[1-3]. Fifteen percent of US adults are estimated to have CKD[2]. There is more than a 50-fold increase in prevalence of patients with earlier stages of CKD (stages 1-4), defined as albuminuria or decreased glomerular filtration rate (GFR), compared with patients who had been treated for kidney failure.[4] Approximately, 26 million individuals (13\% of the noninstitutionalized USA adult population) are now expected to have CKD which represents, an increase from $10 \%$ in last 10 years[4,5]. Ninety six percent of people with kidney damage or mildly reduced kidney function are not aware of having CKD. One in three patients with diabetes develops CKD in their lifetime[6,7].

Irrespective of the severity of CKD, healthy eating is an essential part of a kidney care plan[8,9] as diet may have an adverse effect on other organs[10]. Healthy eating can help reduce the workload on the diseased kidneys and help regulate residual kidney function, control the build-up of wastes in the body, prevent infection, prevent muscle loss and help control blood sugar in the case of diabetes[11].

In the past century, the link between nutrition and human health has also been strongly established by modern science. Emerging evidence also indicates that certain foods or their components might mitigate disease risk[12,13] and promote general health[14,15] and wellbeing[16-19].

Prescribed diets focus on regulating and eliminating unhealthy food components such as saturated and trans fats, sodium, added sugar, etc. Alternatively, the widespread awareness that foods not only provide basic nutrition but can also prevent diseases and ensure good health has now attained greater prominence, thus increasing the quest for potentially beneficial nutrients or Functional Foods (FF) $12,13,20]$. Functional food have been shown to be beneficial for the chronic diseases[14,15,21,22] including cardiovascular disease[23-29], reduction in inflammation of various organs[30-32], protects organ systems[33,34] including brain[35].

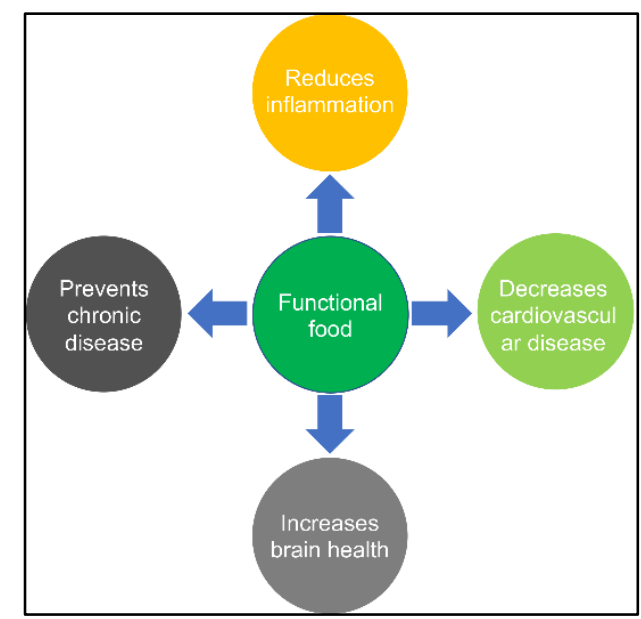

Figure 1: Schematic of functional food and its effect on disease and organ systems. Functional food has a role in reducing inflammation which is responsible for initiation of many diseases. It helps in reducing cardiovascular disease, chronic diseases and improves brain and other organ health.

Schematic diagram for the role of FF on metabolism, its protective effect in disease and its role in organ systems have been shown in Figure 1.

There is no official definition of FFs common to all countries, but the European Union project "Functional Food Science in Europe" (FUFOSE)[36,37] gives an appropriate working definition: "A food can be regarded as 'functional' if it is satisfactorily demonstrated to affect 
beneficially one or more target functions in the body[38], beyond adequate nutritional effects, in a way that is relevant to either an improved state of health and well-being and/or reduction of risk of disease[39,40].

Functional foods must remain foods and they must demonstrate their effects in amounts that can normally be expected to be consumed in the diet: they are not pills or capsules, but part of normal food. In addition to their nutritional characteristics, they positively influence one or more physiological functions[41].

A functional food can be a natural food, a food to which a component has been added, or food from which a component has been removed by technological or biotechnological means. It can also be food where the nature of one or more components has been modified or any combination of these possibilities. A functional food might be functional for all members of a population, or for particular groups of population, which might be defined, for example, by age or by genetic constitution.

Efficacy of functional foods is related to the bioactive compounds and the technical treatments applied to the food. The most important challenge is to ensure that the functional ingredients will survive and remain "active" and "bio-available" even after the processing and storage[41].

Research studies have demonstrated that functional foods when consumed as a part of a custom diet provides significant physiological advantages and is also instrumental in reducing the progression of chronic disease beyond basic nutritional function. This functional property concerns the metabolic or physiological role of the supplement or non-supplement nutrient in development, advancement and other physiological elements of the human body[20].

\section{CKD and Poly Unsaturated Fatty Acids (PUFA)}

The lipids of all higher organisms contain a significant amount of PUFA. PUFA can be classified based on the saturation degree of their carbon chains. Saturated Fatty acids consist of a higher number of hydrogen atoms compared to monounsaturated fatty acids and polyunsaturated fatty acids (PUFAs).

Extensive research and multiple reports have reaffirmed the dietary significance of unsaturated fats and their health benefits concerning cardiovascular disease[23-29] and CKD[42-45]. PUFA's are essential because they cannot be synthesized by the human body. Polyunsaturated fats have reported anti-inflammatory properties[46], which has been suggested, may protect against kidney damage in adults[47].

Studies conducted by De Mello et. al., and others have shown an inverse correlation between the increasing level of albuminuria with polyunsaturated fatty acids (PUFA)[48,49]. Experimental diets with higher PUFA content such as replacing red meat with a chicken-based diet exhibit a reduction in albuminuria and improved serum fatty acid profile[48,50]. This decrease in albuminuria signifies better renal function amongst the intervention study group[48,50].

Reports suggest that dietary administration of polyunsaturated or monounsaturated fatty acids decrease glomerulosclerosis and glomeruli loss in rodent models of diabetic nephropathy and hypertension[51,52]. However, consumption of saturated fats has been reported to be associated with an increase in albuminuria irrespective of the race or diabetes status of the patients[53,54]. Albuminuria has been considered as a reason for diseases like cardiovascular diseases, CKD and mortality. Dietary fat intake is a potentially modifiable behavior that could be a target for intervention in nephropathy. 
It is thus suggested that including dietary nourishment with low quantities of immersed fat or PUFA may be advantageous in prevention of the progression of CKD and can be utilized as a 'supplement'.

\section{Effect of Fish oil on cardiovascular complications and CKD}

Fish oil contains omega fatty acids, which has been reported to have beneficial effects on cardiovascular disease[23-29]. EPA and DHA, both the omega-3 fatty acids may be lower in blood and tissue of patients undergoing dialysis. Thus, dialysis patients need supplementation of EPA and DHA and need to find foods that contain EPA and DHA (i.e., fish and meat)[55]. Fish consumption, which is the primary source of EPA and DHA, may be limited by social dietary habits and financial constraints present in patients undergoing dialysis in the USA. There is a need for the recommendation to the patients with CKD for amount of fish to be taken in their diet. As hemodialysis is found to increase the oxidation, thus, increased omega-3 peroxidation might be happening in the patients undergoing dialysis[56]. Peroxidation causes breakdown of fatty acyl structure and loss of its biologic function. As patients with CKD are kept on low potassium diet, consumption of the omega-3 parent fatty acid ALA should be reduced.

Thus, there is very limited data available on fatty acid levels in dialysis patients. Three studies found low plasma levels of parent omega-3 and/or omega-6 fatty acids[57,58], Arachidonic acid (AA)[57-59], and EPA[59,60] compared with their matched controls. In a fourth study, a low red blood cell membrane EPA levels were found in dialysis patients[60]. Bowden et. al., reports that cardiovascular parameters for hemodialysis patients showed that addition of fish oil (omega-3 fatty acid) containing $160 \mathrm{mg}$ eicosapentaenoic acid (EPA) and $100 \mathrm{mg}$ docosahexaenoic acid (DHA) as compared to corn oil (omega-6 fatty-acid source) for six months indicated that LDL levels were increased more in patients taking corn oil, but HDL levels increased significantly in patients taking fish oil[61]. Thus, this study suggests that EPA and DHA intake can inhibit the rate of increase in LDL and promote the HDL formation. In a larger randomized clinical trial, Svensson et. al., compared omega-3 PUFA supplementation (45\% EPA and 37.5\% DHA) with olive oil (control supplement) in 206 hemodialysis (HD) patients for the period of three months[62]. These data suggest that omega-3 supplemented group had significantly lower serum triglycerides; however, there was no effect on total cholesterol, HDL, LDL, lipoprotein(a), or apoprotein B levels. Similar to the previous studies, Vernaglione et. al., compared omega-3 supplementation ( $2 \mathrm{~g} /$ day) with similar dose of olive oil for four months in $24 \mathrm{HD}$ patients[63]. Although, there were no differences in lipid concentrations between the groups, the systolic, diastolic, and mean blood pressure were significantly lower with the omega-3 intervention[63].

Although the results of these studies are not very consistent, they do suggest that the inexpensive and relatively safe intake of omega- 3 fatty acids may be effective in lowering the risk of cardiovascular disease in HD patients. The mechanism appears to involve modulation of such risk factors like LDL, triglycerides, and BP while increasing HDL, which are protective factors in HD patients.

These findings are not well interpretable because of the following reasons: Contradictory results from these studies, a very small number of patients enrolled in the study (patients number ranging between 9 and 25 except one trial of 206 patients); there are missing data on EPA, DHA, and other fatty acid levels or important fatty acid ratios (e.g., omega-6:omega-3); there is heterogeneity in measurements of parameters (i.e., plasma versus red blood cell levels); differences in demographic and ethnicity (one African, two North American and one 
European,) that could affect omega-3 dietary intake; and heterogeneity in study inclusion criteria. Thus, there is a need for more thorough research to be done in defining omega- 3 status in the dialysis population after considering the above-mentioned parameters.

To compare the amount and the ration of DHA and EPA, we searched for ten popular brands of fish oil containing DHA as well as EPA. Based on the brands we found varying concentrations of DHA and EPA (Table 1). Further, we calculated the ratio of DHA and EPA and found that there are 7 brands out of 10, which have a ratio of $0.65-0.66$ suggesting that this ratio is well accepted for consumption. One of the brands has the lower ratio of 0.50 and two other brands have higher ratio of 0.75-0.80.

Table 1. The levels of intake of DHA and EPA supplied by different brands. The ration of DHA and EPA in the last column showing that the ration of 0.66 is more common.

\begin{tabular}{|l|l|l|l|}
\hline Brand & DHA (mg) & EPA $(\mathbf{m g})$ & Ratio (DHA/EPA) \\
\hline Dr. Martins & 900 & 1200 & 0.75 \\
\hline Advocare Omegaplex & 200 & 300 & 0.66 \\
\hline $\begin{array}{l}\text { Kirkland Signature Natural Fish Oil } \\
\text { Concentrate }\end{array}$ & 100 & 150 & 0.50 \\
\hline Coromega & 230 & 350 & 0.65 \\
\hline Lucky vitamins & 120 & 180 & 0.66 \\
\hline Omega-3 700 & 240 & 360 & 0.66 \\
\hline Carlson Super Omega 3 Fish Oils & 200 & 300 & 0.66 \\
\hline Omega-3 700 & 240 & 360 & 0.66 \\
\hline Omacor & 375 & 465 & 0.80 \\
\hline Vitamin World Naturally Inspired & 200 & 300 & 0.66 \\
\hline
\end{tabular}

\section{Association between CKD and Linolenic acid}

Conjugated Linolenic Acid (CLA) is produced naturally in grass-fed ruminants such as cattle, sheep, buffalo, goats, and in trace amount in chicken and turkey. They are synthesized by fermentative bacteria, Butyrivibrio fibrisolvens, which isomerize the linoleic acid in CLA or by synthesis via $\alpha 9$-desaturase of 11-trans octadecanoic acid [64,65]. CLA is a mixture of isomers of linoleic acid with conjugated double bonds that constitute the most abundant fatty acid with conjugated dienes (CDs) in humans. Conjugated linolenic acid (CLNA) are found in plant seeds, such as catalpa seed, bitter gourd seed, pomegranate seed, trichosanthes seed, tung seed, pot marigold seed, jacaranda seed, and snake gourd seed. Several studies done in humans and animals indicated that CLNA can be metabolized into CLA[66].

Evidence based on animal studies have shown that CLA has anti-atherosclerotic, antidiabetic, anti-inflammatory, and immune-modulating properties[67-71]. A recent study on 3806 men aged between 60-79 without prevalent heart failure followed up for an average of 13 years suggests that high levels of CLA are associated with a lower risk of heart failure[72].

Association of Linolenic acid with CKD has been a controversial topic. Although, the underlying outcomes were discovered only in mice, recent research on patients proposes that CLA would act to lessen adiposity through tempering properties in the lipid metabolism. 
Conjugated linoleic acid (CLA), has been shown to have other benefits for the kidneys as well[73].

CLA is also known to reduce renal production of PGE2, demonstrating a reduction in the inflammation and fibrosis associated with the progression of renal disease [74]. PGE2 leads to a natriuretic effect during increases in renal blood flow [75].

Experiments done with CLA in rats with polycystic kidney disease have shown a significant reduction in Parathyroid hormone (PTH) compared to the control group [76]. PTH elevation in patients with advanced renal diseases is very common and avoiding surgical removal of the thyroid gland by modulating the dietary contents would significantly benefit renal patients.

Be that as it may, questions regarding the mechanisms of action of CLA in adipocytes are yet to be answered.

\section{CKD and Soy}

During the first 50 years of the 20th century, the scientific focus was on the identification of essential elements, particularly vitamins, and their role in the prevention of various dietary deficiency diseases[77,78]. This emphasis on nutrient deficiencies or "under nourishment" shifted dramatically, during the 1970s when diseases linked to excess and "over nutrition" became a major public health concern[79-81]. This change was more prominent in developing countries such as India and China[81,82].

A very low-protein diet is beneficial with $\mathrm{CKD}$, however, too much protein would place undue stress on the kidneys, the possible effects of which include renal calcification, inhibited mineral absorption, and excessive levels of toxic minerals[83,84]. Although proteins are an important nutrient required for the body, it is necessary that the CKD patients on a low protein diet consume proteins in a form that produces the least waste and is readily available to the body without excess protein load on kidneys[84-88].

Some evidence has shown that modifications to the amount and the types of dietary protein, exert a major effect on renal failure thereby limiting dietary protein[89]. Substituting animal protein with soy protein has been suggested to be effective including genetic kidney disease such as polycystic kidney disease[90]. However, there is a lack of clear guidelines based on the scientific evidence, especially in humans.

Soy protein has been claimed to have higher Protein Digestibility Corrected Amino Acid Scores (PDCAAS)[91]. But in spite of the high PDCAAS score, studies have shown that soy protein does not help in the protection of renal function[92]. Thus, this is another controversy in the field and the patients with CKD doesn't have a clear answer in terms of diet management.

Soy protein contains a unique amino acid profile that is different from animal and soy peptides, it includes 4 to 20 amino acids, which may have favorable effects on high blood pressure and hyperlipidemia; thus, soy peptides may be effective in renal function by decreasing proteinuria and associated symptoms [93-97].

Although the effect of soy protein has been well studied in animal models including rats, this statement does not hold true for humans due to lack of available data in human subjects as studied by (Trujillo et. al., 2005)[98] and (Aukema and Housini, 2001)[99]. Reports suggest that rodents and non-human primates, metabolize isoflavones very differently than humans[100] Effect of soy protein in breast cancer was studied in rats and humans and the results suggested that metabolism of soy isoflavones are different in these two species[101]. A comparative study examining the effect of isoflavones suggests confirms that metabolic phenotypes of isoflavones differ among female monkeys, pigs, rats and women [102].

A component of soy that has a reno-protective effect, are the isoflavones [97]. The mechanisms of isoflavones are however not very well known. One of the possibilities for the mechanism of action is by hydrolyzing isoflavones using bacterial $\beta$-glucosidases and changing the bioactive compound: genistein and daidzein in the intestine [103].

Based on the research advances done during past decades, there are 2 schools of thought on the dietary consumption of soy and its effect on renal health. A recent study conducted in 
humans (boys aged 12-14 years) suggests that in addition to inhibiting the digestion of protein, soy plays an important role in reducing the absorption of certain minerals. Phytic acid (phytates) in soy may inhibit calcium absorption as well as the absorption of zinc and iron [104].

In contrast, the reduction of calcium absorption is particularly worrisome since CKD patients are at a higher risk of osteoporosis than the healthy population. The high phytic acid of soy may negate any potential benefits. In another study, phytic acid is shown to induce calcifications in renal papillae in a dose-dependent manner in animal models[29]. High soy diet is excessive in minerals including phosphorus, potassium, albumin and manganese. Excess consumption of phosphorus and potassium with CKD are particularly dangerous with advanced stage renal disease as the kidney isn't equipped in filtering and excreting these minerals and these minerals build up in blood[30].

Inadequate excretion of albumin can cause albumin toxicity to the tubular and other cells of kidneys, which can lead to dialysis encephalopathy in renal patients. This leads some experts to advise people with kidney disease to consult a renal dietician before including soy in the diet.

To study the effects of soy protein on renal function, Ahmed et. al., evaluated "The effect of soy protein on proteinuria and dyslipidemia, in patients with proteinuria glomerulopathy". The results suggest that there is no beneficial effect when using soy protein instead of animal protein[92].

However, in another study conducted by Zhang et. al., revealed soy protein ingestion compared with animal protein feeding significantly decrease serum creatinine and serum phosphorus concentrations in pre-dialysis patients. There were no significant alterations in triglycerides (TG) and Ca levels but TG concentrations were lower [97]. Based on studies involving mice and patients with CKD it has been made summarize that soy protein is a valuable substitute for animal protein[105].

Jing et. al., indicated that soy was related to a significant reduction of proteinuria, serum creatinine, C-reactive protein (CRP) and serum phosphorus in the pre-dialysis subgroup, however, serum phosphorus and CRP did not change in the dialysis subgroup[106]. In the soytreated group, blood urea nitrogen (BUN) was significantly reduced compared with control when two subgroups were analyzed as a whole[106-108]. Thus, this study suggests that soy protein diet restores the kidney function.

Some claim that the discrepancy in the study pertaining to effect of soy in renal disease could be due to evaluating the scenario with an inadequate marker like serum creatinine, which is dependent on various factors like age, gender, diet and muscle mass in humans[109]. Thus, the study done with the recent novel biomarkers for detecting injury of different cell types is needed.

The amount of soy protein consumed can also be a variable factor for determining the effects. For future evaluations, a study group with low and high soy protein should be evaluated with control groups in order to understand the mechanisms of action and effects of soy protein. Use of a significant renal marker like KIM-1[110,111], NGAL[112,113] or cystatin C[114116] in combination with other novel biomarkers[117], which determines the effect on kidney function more accurately should be taken into consideration[118,119].

\section{CKD and Vitamin $B$}

The typical renal failure diet is low in B-vitamins. Virtually all un-supplemented "pre-dialysis" and dialysis patients develop pyridoxine $\left(\mathrm{B}_{6}\right)$ deficiency (exacerbated by high-flux HD), Cyanocobalamin $\left(\mathrm{B}_{12}\right)$ deficiency (protein bound-deficiency not common in dialysis) and Folic acid deficiency can occur in un-supplemented CKD patients.

Healthy kidneys produce a hormone called Erythropoietin (EPO). EPO signals the bone marrow to make red blood cells, which then carry oxygen throughout the body. When the kidneys are diseased or damaged, the kidney cells express significantly less amount of EPO[120-122]. As a result, the bone marrow makes fewer red blood cells, which leads 
to anemia. Other common causes of anemia in people with kidney disease include blood loss from hemodialysis and low levels of vitamin $\mathrm{B}_{12}$ and folic acid from their diet.

It is also pertinent to mention that there is ongoing research being conducted on the pros and cons of vitamin therapy for patients with CKD. Various studies are also being conducted on the suppression of hyper-homocysteinemia and prevention of cardiovascular disease[123].

Switching to a diet based on animal products increases the availability of vitamin B and vitamin $\mathrm{K}$ especially for patients with kidney disease. A study conducted by Amini et. al., on the advantages of supplementing Vitamin $\mathrm{B}_{12}$ to end stage renal disease patients showed that injection rather than an oral dosage of vitamin $\mathrm{B}_{12}$ was more efficient especially when combined with folate is accompanied by a decrease in homocysteine levels[124]. Elevated levels of homocysteine are associated with increased levels of cardiovascular inflammation. A low level of $\mathrm{B}_{12}$ has also been associated with albuminuria [125].

\section{CKD and L-Carnitine}

L-carnitine is a derivative of the amino acid, lysine. The name L-Carnitine is derived from the fact that it was first isolated from meat. It is a conditionally essential nutrient obtained both from diet and endogenous production in the body. Impaired intra-renal synthesis of L-carnitine or its reabsorption by tubular cells of CKD patients can lead to carnitine deficiency[126]. It has also been termed as vitamin $\mathrm{B}_{\mathrm{T}}$.

Table 2: The levels of intake of CLA by 10 different leading suppliers. Based on these levels, an average intake of $2060 \mathrm{mg}$ is calculated.

\begin{tabular}{|l|l|}
\hline Brand & CLA (mg) \\
\hline GNC & 2000 \\
\hline Olympian Labs & 3000 \\
\hline Now Foods & 1600 \\
\hline Natrol & 2400 \\
\hline Med-Rx & 2000 \\
\hline Barlean's & 3000 \\
\hline Solgar & 2600 \\
\hline County life & 2000 \\
\hline Vita Essentials & 1000 \\
\hline Arazo Nutrients & 1000 \\
\hline
\end{tabular}

Renal reabsorption of L-carnitine is normally very efficient and therefore, carnitine excretion by the kidney is normally very low. Malfunction of the kidney consequently results in increased urinary losses of carnitine[127,128]. Carnitine depletion may lead to a number of conditions observed in dialysis patients, including, plasma lipid abnormalities, muscle weakness and, fatigue and refractory anemia.

The National Kidney Foundation (NKF) does not recommend routine administration of Lcarnitine to all dialysis patients. However, the NKF and other consensus groups suggest a trial of L-carnitine for hemodialysis patients with selected symptoms that do not respond to standard therapy. Those symptoms include cardiomyopathy, persistent muscle cramps, skeletal muscle weakness or myopathy, hypotension (low blood pressure) during dialysis, severe fatigue, and anemia that requires administration of erythropoietin (EPO)[129]. We investigated 10 leading brands of L-Carnitine available in the market and found that the supplement dose is ranging 
from $1600 \mathrm{mg} /$ day to $3000 \mathrm{mg} /$ day. The mean dose calculated on these 10 brands is 2060 $\mathrm{mg} /$ day as shown in Table 2.

Table 3. Summary of the functional food components, its sources and its known targets from different research studies.

\begin{tabular}{|c|c|c|c|}
\hline S1. No. & $\begin{array}{l}\text { Functional } \\
\text { food }\end{array}$ & Main sources & Mechanisms of action/targets \\
\hline 1 & $\begin{array}{l}\text { Conjugated } \\
\text { Linolenic } \\
\text { Acid }\end{array}$ & $\begin{array}{l}\text { Flaxseeds and flaxseed oil, } \\
\text { canola (rapeseed) oil, } \\
\text { Soybeans and soybean oil } \\
\text { Pumpkin seeds and pumpkin seed oil, } \\
\text { perilla seed oil, tofu, walnuts and its oil. }\end{array}$ & $\begin{array}{l}\text { Reduce production of PGE2 by kidney[74]. } \\
\text { Reduction in the inflammation and fibrosis associated } \\
\text { with the progression of renal disease[74]. } \\
\text { Reduction in the level of Parathyroid Hormone and hence } \\
\text { prevents surgical removal of thyroid gland in patients with } \\
\text { CKD[76]. }\end{array}$ \\
\hline 2 & Soy & $\begin{array}{l}\text { Edamame, meat alternatives, miso sauce, } \\
\text { soymilk, soy nuts, soy sauce (tamari, } \\
\text { shoyu and teriyaki), tempeh, textured soy } \\
\text { protein. }\end{array}$ & $\begin{array}{l}\text { Favorable effects on high BP and hyperlipidemia[93-96]. } \\
\text { Isoflavones a component of soy has a protective effect on } \\
\text { kidney[97]. } \\
\text { Mixed opinions on consumption of soy with regards to } \\
\text { calcification levels and effect on CKD patients. } \\
\text { Improves SCr and serum phosphorus concentrations in } \\
\text { pre-dialysis patients[93-96]. } \\
\text { Reduces proteinuria, SCr, C-reactive protein (CRP) and } \\
\text { serum phosphorus in the pre-dialysis patients[93-96]. }\end{array}$ \\
\hline 3 & Vitamin B & $\begin{array}{l}\text { B }_{1} \text { (Thiamine): Brown rice, veggies, fruits, } \\
\text { seafood, sunflower seeds, whole grains. } \\
\text { B }_{2} \text { (Riboflavin): Salmon, broccoli, } \\
\text { spinach, eggs, almonds, meat. } \\
\text { B }_{3} \text { (Niacin): Peanuts, liver, chicken, many } \\
\text { fish, brown rice. } \\
\text { B }_{5} \text { (Pantothenic acid): Liver, mushrooms, } \\
\text { legumes, veggies, nuts, avocado. } \\
\text { B }_{6} \text { (Pyridoxine): Trout, molasses, poultry, } \\
\text { blueberries. } \\
\text { B }_{7} \text { (Biotin): Egg yolk, organ meats, milk, } \\
\text { barley, yeast royal jelly. } \\
\text { B }_{9} \text { (Folic acid): Leafy greens, berries, } \\
\text { citrus fruits, legumes, salmon, spinach, } \\
\text { eggs. } \\
\text { B }_{12} \text { (Cobalamin): Trout, liver, beef, eggs, } \\
\text { salmon, milk, shellfish. }\end{array}$ & $\begin{array}{l}\text { Prevents albuminuria[131]. } \\
\text { Inhibits anemia due to blood loss from hemodialysis[132]. } \\
\text { Suppression of hyper-homocysteinemia and prevention of } \\
\text { Cardiovascular disease[123]. }\end{array}$ \\
\hline 4 & L-Carnitine & $\begin{array}{l}\text { Beef, milk, codfish, chicken breast, ice } \\
\text { cream, cheddar cheese, whole wheat } \\
\text { bread, asparagus. }\end{array}$ & $\begin{array}{l}\text { Reduces muscle weaknesses and fatigue. } \\
\text { Reduces plasma lipid abnormalities[133]. } \\
\text { Reduces anemia. } \\
\text { Increases production of EPO[134]. }\end{array}$ \\
\hline
\end{tabular}




\section{CONCLUSIONS}

There is mounting evidence that functional foods may enhance health, but the field of functional foods is still in a preliminary stage. Claims about the health benefits of functional foods must be based on sound scientific criteria [130]. Extensive research is necessary to substantiate the potential health benefits of those foods for which the diet-health relationships are not sufficiently scientifically validated. Research into functional foods will not advance public health unless the benefits of the foods are effectively communicated to the consumer.

The need of the hour is to make nutrition health the point of focus and thereby eliminate the negative aspect of the renal diet. Though a lot of effort is on to educate and make people aware to select healthier food choices, better outreach through targeted campaigns and nutrition education for kidney health providers and patients is required.

Thus, there is a need for a thorough investigation of the functional food and its active ingredients for the betterment of patients with CKD and its associated complications.

List of Abbreviations: Chronic Kidney Disease, CKD; Prostaglandins E2, PGE2; Erythropoietin, EPO; Serum Creatinine, SCr; Blood Urea Nitrogen, BUN; Protein Digestibility Corrected Amino Acid Scores, PDCAAS; Conjugated Linolenic Acid, CLA; Polyunsaturated Fatty Acids, PUFAs, Kidney Injury Molecule-1, KIM-1; C Reactive Protein, CRP, High Density Lipoprotein, HDL; Low Density Lipoprotein, LDL.

Competing Interests: The authors have no financial disclose or any other conflict of interests.

Authors' Contributions: A.K.A. conceived the idea and supervised S.V. to write the manuscript. S.V. searched the literature and wrote the draft. A.K.A. and V.S.S. edited the manuscript. All authors approve the final manuscript.

Acknowledgements and Funding: A.K.A. is supported by Career Development Award from American Heart Association, 19CDA34780005.

\section{REFERENCES:}

1. Heron M: Deaths: Leading Causes for 2013. Natl Vital Stat Rep 2016, 65(2):1-95.

2. De Boer IH, Rue TC, Hall YN, Heagerty PJ, Weiss NS, Himmelfarb J: Temporal trends in the prevalence of diabetic kidney disease in the United States. JAMA 2011, 305(24):2532-2539.

3. Tamadon MR, Ardalan MR, Nasri H: World Kidney Day 2013; acute renal injury; a global health warning. Journal of Parathyroid Disease 2013, 1(2):27-28.

4. Coresh J, Selvin E, Stevens LA, Manzi J, Kusek JW, Eggers P, Van Lente F, et al.: Prevalence of chronic kidney disease in the United States. JAMA 2007, 298(17):20382047.

5. Coresh J, Astor BC, Greene T, Eknoyan G, Levey AS: Prevalence of chronic kidney disease and decreased kidney function in the adult US population: Third National Health and Nutrition Examination Survey. Am J Kidney Dis 2003, 41(1):1-12.

6. Afkarian M, Katz R, Bansal N, Correa A, Kestenbaum B, Himmelfarb J, de Boer IH, et al.: Diabetes, Kidney Disease, and Cardiovascular Outcomes in the Jackson Heart Study. Clin J Am Soc Nephrol 2016, 11(8):1384-1391. 
7. Afkarian M, Zelnick LR, Hall YN, Heagerty PJ, Tuttle K, Weiss NS, de Boer IH: Clinical Manifestations of Kidney Disease Among US Adults With Diabetes, 1988-2014. JAMA 2016, 316(6):602-610.

8. Mafra D, Borges N, Alvarenga L, Esgalhado M, Cardozo L, Lindholm B, Stenvinkel P: Dietary Components That May Influence the Disturbed Gut Microbiota in Chronic Kidney Disease. Nutrients 2019, 11(3):pii:E496.

9. Shimada M, Shutto-Uchita Y, Yamabe H: Lack of Awareness of Dietary Sources of Phosphorus Is a Clinical Concern. In Vivo 2019, 33(1):11-16.

10. Jazani NH, Savoj J, Lustgarten M, Lau WL, Vaziri ND: Impact of Gut Dysbiosis on Neurohormonal Pathways in Chronic Kidney Disease. Diseases 2019, 7(1):pii:E21.

11. Sulaiman MK: Diabetic nephropathy: recent advances in pathophysiology and challenges in dietary management. Diabetol Metab Syndr 2019, 11:7.

12. Mattei D, Pietrobelli A: Micronutrients and Brain Development. Curr Nutr Rep 2019, 8(2):99-107.

13. Wlodarek D: Role of Ketogenic Diets in Neurodegenerative Diseases (Alzheimer's Disease and Parkinson's Disease). Nutrients 2019, 11(1):pii:E169.

14. Hudak KM, Racine EF: The Supplemental Nutrition Assistance Program and Child Weight Status: A Review. Am J Prev Med 2019, 56(6):882-893.

15. Zhang X, Liu RP, Cheng WH, Zhu JH: Prioritized brain selenium retention and selenoprotein expression: Nutritional insights into Parkinson's disease. Mech Ageing Dev 2019, 180:89-96.

16. Ter Borg S, Koopman N, Verkaik-Kloosterman J: Food Consumption, Nutrient Intake and Status during the First 1000 days of Life in the Netherlands: a Systematic Review. Nutrients 2019, 11(4):pii:E860

17. Johnson M, Fransson G, Ostlund S, Areskoug B, Gillberg C: Omega 3/6 fatty acids for reading in children: a randomized, double-blind, placebo-controlled trial in 9-year-old mainstream schoolchildren in Sweden. J Child Psychol Psychiatry 2017, 58(1):83-93.

18. Bruins MJ, Van Dael P, Eggersdorfer M: The Role of Nutrients in Reducing the Risk for Noncommunicable Diseases during Aging. Nutrients 2019, 11(1):pii:E85.

19. Doherty R, Madigan S, Warrington G, Ellis J: Sleep and Nutrition Interactions: Implications for Athletes. Nutrients 2019, 11(4):pii:E822.

20. Hasler CM: Functional foods :their role in disease prevention and health promotion. Food Technology 1998, 52(11):50-63.

21. Alkhatib A, Tsang C, Tiss A, Bahorun T, Arefanian H, Barake R, Khadir A, et al.: Functional Foods and Lifestyle Approaches for Diabetes Prevention and Management. Nutrients 2017, 9(12):pii:E1310.

22. Kouidi E: Health-related quality of life in end-stage renal disease patients: the effects of renal rehabilitation. Clin Nephrol 2004, 61(Suppl 1):S60-71.

23. Kopple JD: National kidney foundation K/DOQI clinical practice guidelines for nutrition in chronic renal failure. Am J Kidney Dis 2001, 37(1 Suppl 2):S66-70.

24. Pang KL, Chin KY: The Role of Tocotrienol in Protecting Against Metabolic Diseases. Molecules 2019, 24(5):pii:E923. 
25. Abdelhamid AS, Brown TJ, Brainard JS, Biswas P, Thorpe GC, Moore HJ, Deane KH, et al.: Omega-3 fatty acids for the primary and secondary prevention of cardiovascular disease. Cochrane Database Syst Rev 2018, 11:CD003177.

26. Alhassan A, Young J, Lean MEJ, Lara J: Consumption of fish and vascular risk factors: A systematic review and meta-analysis of intervention studies. Atherosclerosis 2017, 266:87-94.

27. Kiefte-de Jong JC, Chowdhury R, Franco OH: Fish intake or omega-3 fatty acids: greater than the sum of all parts? Eur J Epidemiol 2012, 27(12):891-894.

28. Chowdhury R, Stevens S, Gorman D, Pan A, Warnakula S, Chowdhury S, Ward H, et al.: Association between fish consumption, long chain omega 3 fatty acids, and risk of cerebrovascular disease: systematic review and meta-analysis. BMJ 2012, 345:e6698.

29. Clarke R, Daly L, Robinson K, Naughten E, Cahalane S, Fowler B, Graham I: Hyperhomocysteinemia: an independent risk factor for vascular disease. N Engl J Med 1991, 324:1149-1155.

30. Mijan MA, Lim BO: Diets, functional foods, and nutraceuticals as alternative therapies for inflammatory bowel disease: Present status and future trends. World J Gastroenterol 2018, 24(25):2673-2685.

31. Ma L, Sun Z, Zeng Y, Luo M, Yang J: Molecular Mechanism and Health Role of Functional Ingredients in Blueberry for Chronic Disease in Human Beings. Int J Mol Sci 2018, 19(9):2785.

32. Summerhill V, Karagodin V, Grechko A, Myasoedova V, Orekhov A: Vasculoprotective Role of Olive Oil Compounds via Modulation of Oxidative Stress in Atherosclerosis. Front Cardiovasc Med 2018, 5:188.

33. Yang J, Fernandez-Galilea M, Martinez-Fernandez L, Gonzalez-Muniesa P, PerezChavez A, Martinez JA, Moreno-Aliaga MJ: Oxidative Stress and Non-Alcoholic Fatty Liver Disease: Effects of Omega-3 Fatty Acid Supplementation. Nutrients 2019, 11(4):872.

34. Deng Y, Tang K, Chen R, Nie H, Liang S, Zhang J, Zhang Y, et al.: Berberine attenuates hepatic oxidative stress in rats with non-alcoholic fatty liver disease via the Nrf2/ARE signalling pathway. Exp Ther Med 2019, 17(3):2091-2098.

35. Xing L, Zhang H, Qi R, Tsao R, Mine Y: Recent Advances in the Understanding of the Health Benefits and Molecular Mechanisms Associated with Green Tea Polyphenols. J Agric Food Chem 2019, 67(4):1029-1043.

36. Contor L: Functional Food Science in Europe. Nutr Metab Cardiovasc Dis 2001, 11(4 Suppl):20-23.

37. Roberfroid MB: Global view on functional foods: European perspectives. Br J Nutr 2002, 88(Suppl 2):S133-138.

38. Scientific concepts of functional foods in Europe. Consensus document. Br J Nutr 1999, 81(Suppl 1):S1-27.

39. Bellisle F, Blundell JE, Dye L, Fantino M, Fern E, Fletcher RJ, Lambert J, et al.: Functional food science and behaviour and psychological functions. Br J Nutr 1998, 80(Suppl 1):S173-193.

40. Taylor SE, Feld HJ: Promoting functional foods and nutraceuticals on the Internet. Food Drug Law J 1999, 54(3):423-451. 
41. Milner JA: Functional foods and health promotion. J Nutr 1999, 129(7 Suppl):1395S$1397 \mathrm{~S}$.

42. Pastor M, Basas J, Vairo C, Gainza G, Moreno-Sastre M, Gomis X, Fleischer A, et al.: Safety and effectiveness of sodium colistimethate-loaded nanostructured lipid carriers (SCM-NLC) against $\mathrm{P}$. aeruginosa: in vitro and in vivo studies following pulmonary and intramuscular administration. Nanomedicine 2019, 18:101-111.

43. Saglimbene VM, Wong G, van Zwieten A, Palmer SC, Ruospo M, Natale P, Campbell $\mathrm{K}$, et al.: Effects of omega-3 polyunsaturated fatty acid intake in patients with chronic kidney disease: Systematic review and meta-analysis of randomized controlled trials. Clin Nutr 2019, pii:S0261-5614.

44. Zanetti M, Gortan Cappellari G, Barbetta D, Semolic A, Barazzoni R: Omega 3 Polyunsaturated Fatty Acids Improve Endothelial Dysfunction in Chronic Renal Failure: Role of eNOS Activation and of Oxidative Stress. Nutrients 2017, 9(8):pii:E895.

45. Baggio B, Musacchio E, Priante G: Polyunsaturated fatty acids and renal fibrosis: pathophysiologic link and potential clinical implications. J Nephrol 2005, 18(4):362367.

46. Wakimoto T, Kondo H, Nii H, Kimura K, Egami Y, Oka Y, Yoshida M, et al.: Furan fatty acid as an anti-inflammatory component from the green-lipped mussel Perna canaliculus. Proc Natl Acad Sci U S A 2011, 108(42):17533-17537.

47. Calder PC: Polyunsaturated fatty acids, inflammation, and immunity. Lipids 2001, 36(9):1007-1024.

48. de Mello VD, Zelmanovitz T, Perassolo MS, Azevedo MJ, Gross JL: Withdrawal of red meat from the usual diet reduces albuminuria and improves serum fatty acid profile in type 2 diabetes patients with macroalbuminuria. Am J Clin Nutr 2006, 83(5):1032-1038.

49. Navaneethan SD, Virani SS: Omega-3 Fatty Acids (Fish Oil) Supplementation and Albuminuria: Not a Slam Dunk. J Am Heart Assoc 2017, 6(7):pii:e006020.

50. Elajami TK, Alfaddagh A, Lakshminarayan D, Soliman M, Chandnani M, Welty FK: Eicosapentaenoic and Docosahexaenoic Acids Attenuate Progression of Albuminuria in Patients With Type 2 Diabetes Mellitus and Coronary Artery Disease. J Am Heart Assoc 2017, 6 .

51. Aguila MB, Pinheiro AR, Aquino JC, Gomes AP, Mandarim-de-Lacerda CA: Different edible oil beneficial effects (canola oil, fish oil, palm oil, olive oil, and soybean oil) on spontaneously hypertensive rat glomerular enlargement and glomeruli number. Prostaglandins Other Lipid Mediat 2005, 76(1-4):74-85.

52. Yokoyama M, Tanigawa K, Murata T, Kobayashi Y, Tada E, Suzuki I, Nakabou Y, et al.: Dietary polyunsaturated fatty acids slow the progression of diabetic nephropathy in streptozotocin-induced diabetic rats. Nutr Res 2010, 30(3):217-225.

53. Verhave JC, Gansevoort RT, Hillege HL, Bakker SJ, De Zeeuw D, de Jong PE, Group PS: An elevated urinary albumin excretion predicts de novo development of renal function impairment in the general population. Kidney Int Suppl 2004, 92:S18-21.

54. Odermatt A: The Western-style diet: a major risk factor for impaired kidney function and chronic kidney disease. Am J Physiol Renal Physiol 2011, 301(5):F919-931. 
55. Dobell E, Chan M, Williams P, Allman M: Food preferences and food habits of patients with chronic renal failure undergoing dialysis. J Am Diet Assoc 1993, 93(10):1129_ 1135.

56. Ikizler TA, Morrow JD, Roberts LJ, Evanson JA, Becker B, Hakim RM, Shyr Y, et al.: Plasma F2-isoprostane levels are elevated in chronic hemodialysis patients. Clin Nephrol 2002, 58(3):190-197.

57. Dasgupta A, Kenny MA, Ahmad S: Abnormal fatty acid profile in chronic hemodialysis patients: possible deficiency of essential fatty acids. Clin Physiol Biochem 1990, 8(5):238-243.

58. Varga Z, Karpati I, Paragh G, Buris L, Kakuk G: Relative abundance of some free fatty acids in plasma of uremic patients: relationship between fatty acids, lipid parameters, and diseases. Nephron 1997, 77(4):417-421.

59. Peck LW, Monsen ER, Ahmad S: Effect of three sources of long-chain fatty acids on the plasma fatty acid profile, plasma prostaglandin E2 concentrations, and pruritus symptoms in hemodialysis patients. Am J Clin Nutr 1996, 64(2):210-214.

60. Koorts AM, Viljoen M, Kruger MC: Red blood cell fatty acid profile of chronic renal failure patients receiving maintenance haemodialysis treatment. Prostaglandins Leukot Essent Fatty Acids 2002, 67(1):13-18.

61. Bowden RG, Jitomir J, Wilson RL, Gentile M: Effects of omega-3 fatty acid supplementation on lipid levels in endstage renal disease patients. J Ren Nutr 2009, 19(4):259-266.

62. Svensson M, Schmidt EB, Jorgensen KA, Christensen JH: The effect of n-3 fatty acids on lipids and lipoproteins in patients treated with chronic haemodialysis: a randomized placebo-controlled intervention study. Nephrol Dial Transplant 2008, 23(9):2918-2924.

63. Vernaglione L, Cristofano C, Chimienti S: Omega-3 polyunsaturated fatty acids and proxies of cardiovascular disease in hemodialysis: a prospective cohort study. J Nephrol 2008, 21(1):99-105.

64. Ogawa J, Kishino S, Ando A, Sugimoto S, Mihara K, Shimizu S: Production of conjugated fatty acids by lactic acid bacteria. J Biosci Bioeng 2005, 100(4):355-364.

65. Kepler CR, Hirons KP, McNeill JJ, Tove SB: Intermediates and products of the biohydrogenation of linoleic acid by Butyrinvibrio fibrisolvens. J Biol Chem 1966, 241(6):1350-1354.

66. Yuan G, Sinclair AJ, Xu C, Li D: Incorporation and metabolism of punicic acid in healthy young humans. Mol Nutr Food Res 2009, 53(10):1336-1342.

67. Shokryzadan P, Rajion MA, Meng GY, Boo LJ, Ebrahimi M, Royan M, Sahebi M, et al.: Conjugated linoleic acid: A potent fatty acid linked to animal and human health. Crit Rev Food Sci Nutr 2017, 57(13):2737-2748.

68. Dilzer A, Park Y: Implication of conjugated linoleic acid (CLA) in human health. Crit Rev Food Sci Nutr 2012, 52(6):488-513.

69. Bhattacharya A, Banu J, Rahman M, Causey J, Fernandes G: Biological effects of conjugated linoleic acids in health and disease. J Nutr Biochem 2006, 17(12):789-810.

70. Mensink RP: Metabolic and health effects of isomeric fatty acids. Curr Opin Lipidol 2005, 16(1):27-30. 
71. Tricon S, Yaqoob P: Conjugated linoleic acid and human health: a critical evaluation of the evidence. Curr Opin Clin Nutr Metab Care 2006, 9(2):105-110.

72. Wannamethee SG, Jefferis BJ, Lennon L, Papacosta O, Whincup PH, Hingorani AD: Serum Conjugated Linoleic Acid and Risk of Incident Heart Failure in Older Men: The British Regional Heart Study. J Am Heart Assoc 2018, 7(1):pii:e006653.

73. Wakefield AP, Ogborn MR, Ibrahim N, Aukema HM: A dietary conjugated linoleic acid treatment that slows renal disease progression alters renal cyclooxygenase-2-derived prostanoids in the Han: SPRD-cy rat. J Nutr Biochem 2012, 23(8):908-914.

74. Ogborn MR, Nitschmann E, Bankovic-Calic N, Weiler HA, Fitzpatrick-Wong S, Aukema HM: Dietary conjugated linoleic acid reduces PGE2 release and interstitial injury in rat polycystic kidney disease. Kidney Int 2003, 64(4):1214-1221.

75. Villa E, Garcia-Robles R, Haas J, Romero JC: Comparative effect of PGE2 and PGI2 on renal function. Hypertension 1997, 30(3 Pt 2):664-666.

76. The Role of Conjugated Linoleic Acid in Human Health. Proceedings of a workshop: Winnipeg, Canada, March 13-15 March 2003. Am J Clin Nutr 2004, 79(6 Suppl):1131S1220S.

77. Popkin BM: Dynamics of the nutrition transition and its implications for the developing world. Forum Nutr 2003, 56:262-264.

78. Popkin BM, Du S: Dynamics of the nutrition transition toward the animal foods sector in China and its implications: a worried perspective. J Nutr 2003, 133(11 Suppl 2):3898S-3906S.

79. Popkin BM: What can public health nutritionists do to curb the epidemic of nutritionrelated noncommunicable disease? Nutr Rev 2009, 67(Suppl 1):S79-82.

80. Popkin BM: Global changes in diet and activity patterns as drivers of the nutrition transition. Nestle Nutr Workshop Ser Pediatr Program 2009, 63:1-10; discussion 10-14, 259-268.

81. Shetty PS: Nutrition transition in India. Public Health Nutr 2002, 5(1A):175-182.

82. Popkin BM, Horton S, Kim S, Mahal A, Shuigao J: Trends in diet, nutritional status, and diet-related noncommunicable diseases in China and India: the economic costs of the nutrition transition. Nutr Rev 2001, 59(12):379-390.

83. Rhee CM, Ahmadi SF, Kovesdy CP, Kalantar-Zadeh K: Low-protein diet for conservative management of chronic kidney disease: a systematic review and metaanalysis of controlled trials. J Cachexia Sarcopenia Muscle 2018, 9(2):235-245.

84. Kovesdy CP, Kalantar-Zadeh K: Back to the future: restricted protein intake for conservative management of $\mathrm{CKD}$, triple goals of renoprotection, uremia mitigation, and nutritional health. Int Urol Nephrol 2016, 48(5):725-729.

85. Wang M, Chou J, Chang Y, Lau WL, Reddy U, Rhee CM, Chen J, et al.: The role of low protein diet in ameliorating proteinuria and deferring dialysis initiation: what is old and what is new. Panminerva Med 2017, 59(2):157-165.

86. Ko BJ, Chang Y, Ryu S, Kim EM, Lee MY, Hyun YY, Lee KB: Dietary acid load and chronic kidney disease in elderly adults: Protein and potassium intake. PLoS One 2017, 12(9):e0185069.

87. Ko GJ, Obi Y, Tortorici AR, Kalantar-Zadeh K: Dietary protein intake and chronic kidney disease. Curr Opin Clin Nutr Metab Care 2017, 20(1):77-85. 
88. Klahr S, Levey AS, Beck GJ, Caggiula AW, Hunsicker L, Kusek JW, Striker G: The effects of dietary protein restriction and blood-pressure control on the progression of chronic renal disease. Modification of Diet in Renal Disease Study Group. N Engl J Med 1994, 330(13):877-884.

89. Nazar CMJ: Significance of diet in chronic kidney disease. J Nephropharmacol 2013, 2(2):37-43.

90. Aukema HM, Housini I, Rawling JM: Dietary soy protein effects on inherited polycystic kidney disease are influenced by gender and protein level. J Am Soc Nephrol 1999, 10(2):300-308.

91. Hughes GJ, Ryan DJ, Mukherjea R, Schasteen CS: Protein digestibility-corrected amino acid scores (PDCAAS) for soy protein isolates and concentrate: criteria for evaluation. J Agric Food Chem 2011, 59(23):12707-12712.

92. Ahmed MS, Calabria AC, Kirsztajn GM: Short-term effects of soy protein diet in patients with proteinuric glomerulopathies. J Bras Nefrol 2011, 33(2):150-159.

93. Cupisti A, D'Alessandro C, Ghiadoni L, Morelli E, Panichi V, Barsotti G: Effect of a soy protein diet on serum lipids of renal transplant patients. J Ren Nutr 2004, 14(1):31-35.

94. Cupisti A, Ghiadoni L, D'Alessandro C, Kardasz I, Morelli E, Panichi V, Locati D, et al.: Soy protein diet improves endothelial dysfunction in renal transplant patients. Nephrol Dial Transplant 2007, 22(1):229-234.

95. D'Amico G, Gentile MG, Manna G, Fellin G, Ciceri R, Cofano F, Petrini C, et al.: Effect of vegetarian soy diet on hyperlipidaemia in nephrotic syndrome. Lancet 1992, 339(8802):1131-1134.

96. D'Amico G, Gentile MG: Effect of dietary manipulation on the lipid abnormalities and urinary protein loss in nephrotic patients. Miner Electrolyte Metab 1992, 18(2-5):203206.

97. Zhang J, Liu J, Su J, Tian F: The effects of soy protein on chronic kidney disease: a metaanalysis of randomized controlled trials. Eur J Clin Nutr 2014, 68(9):987-993.

98. Trujillo J, Ramirez V, Perez J, Torre-Villalvazo I, Torres N, Tovar AR, et al.: Renal protection by a soy diet in obese Zucker rats is associated with restoration of nitric oxide generation. Am J Physiol Renal Physiol 2005, 288(1):F108-116.

99. Aukema HM, Housini I: Dietary soy protein effects on disease and IGF-I in male and female Han:SPRD-cy rats. Kidney Int 2001, 59(1):52-61.

100. Soukup ST, Helppi J, Muller DR, Zierau O, Watzl B, Vollmer G, Diel P, et al.: Phase II metabolism of the soy isoflavones genistein and daidzein in humans, rats and mice: a cross-species and sex comparison. Arch Toxicol 2016, 90(6):1335-1347.

101. Setchell KD, Brown NM, Zhao X, Lindley SL, Heubi JE, King EC, Messina MJ: Soy isoflavone phase II metabolism differs between rodents and humans: implications for the effect on breast cancer risk. Am J Clin Nutr 2011, 94(5):1284-1294.

102. Gu L, House SE, Prior RL, Fang N, Ronis MJ, Clarkson TB, Wilson ME, et al.: Metabolic phenotype of isoflavones differ among female rats, pigs, monkeys, and women. J Nutr 2006, 136(5):1215-1221.

103. Ricketts ML, Moore DD, Banz WJ, Mezei O, Shay NF: Molecular mechanisms of action of the soy isoflavones includes activation of promiscuous nuclear receptors. A review. J Nutr Biochem 2005, 16(6):321-330. 
104. Zhao XF, Hao LY, Yin SA, Kastenmayor P, Barclay D: [A study on absorption and utilization of calcium, iron and zinc in mineral-fortified and dephytinized soy milk powder consumed by boys aged 12 to 14 years]. Zhonghua Yu Fang Yi Xue Za Zhi 2003, 37(1):5-8.

105. Rafieian-Kopaei M, Beigrezaei S, Nasri H, Kafeshani M: Soy Protein and Chronic Kidney Disease: An Updated Review. Int J Prev Med 2017, 8:105.

106. Jing Z, Wei-Jie Y: Effects of soy protein containing isoflavones in patients with chronic kidney disease: A systematic review and meta-analysis. Clin Nutr 2016, 35(1):117-124.

107. Waikar SS, Betensky RA, Bonventre JV: Creatinine as the gold standard for kidney injury biomarker studies? Nephrol Dial Transplant 2009, 24(11):3263-3265.

108. Bjornsson TD: Use of serum creatinine concentrations to determine renal function. Clin Pharmacokinet 1979, 4(3):200-222.

109. Bosch JP, Saccaggi A, Lauer A, Ronco C, Belledonne M, Glabman S: Renal functional reserve in humans. Effect of protein intake on glomerular filtration rate. Am J Med 1983, 75(6):943-950.

110. Krolewski AS, Gohda T, Niewczas MA: Progressive renal decline as the major feature of diabetic nephropathy in type 1 diabetes. Clin Exp Nephrol 2014, 18(4):571-583.

111. Krolewski AS, Niewczas MA, Skupien J, Gohda T, Smiles A, Eckfeldt JH, Doria A, et al.: Early progressive renal decline precedes the onset of microalbuminuria and its progression to macroalbuminuria. Diabetes Care 2014, 37(1):226-234.

112. Bolignano D, Donato V, Coppolino G, Campo S, Buemi A, Lacquaniti A, Buemi M: Neutrophil gelatinase-associated lipocalin (NGAL) as a marker of kidney damage. Am J Kidney Dis 2008, 52(3):595-605.

113. Bolignano D, Coppolino G, Campo S, Aloisi C, Nicocia G, Frisina N, Buemi M: Urinary neutrophil gelatinase-associated lipocalin (NGAL) is associated with severity of renal disease in proteinuric patients. Nephrol Dial Transplant 2008, 23(1):414-416.

114. Shlipak MG, Coresh J, Gansevoort RT: Cystatin C versus creatinine for kidney functionbased risk. N Engl J Med 2013, 369(25):2459.

115. Shlipak MG, Matsushita K, Arnlov J, Inker LA, Katz R, Polkinghorne KR, Rothenbacher $\mathrm{D}$, et al.: Cystatin $\mathrm{C}$ versus creatinine in determining risk based on kidney function. $\mathrm{N}$ Engl J Med 2013, 369(10):932-943.

116. Shlipak MG, Mattes MD, Peralta CA: Update on cystatin C: incorporation into clinical practice. Am J Kidney Dis 2013, 62(3):595-603.

117. Craciun FL, Bijol V, Ajay AK, Rao P, Kumar RK, Hutchinson J, Hofmann O, et al.: RNA Sequencing Identifies Novel Translational Biomarkers of Kidney Fibrosis. J Am Soc Nephrol 2016, 27(6):1702-1713.

118. Taub PR, Borden KC, Fard A, Maisel A: Role of biomarkers in the diagnosis and prognosis of acute kidney injury in patients with cardiorenal syndrome. Expert Rev Cardiovasc Ther 2012, 10(5):657-667.

119. Malhotra R, Siew ED: Biomarkers for the Early Detection and Prognosis of Acute Kidney Injury. Clin J Am Soc Nephrol 2017, 12(1):149-173.

120. Tanaka T, Nangaku M: Recent advances and clinical application of erythropoietin and erythropoiesis-stimulating agents. Exp Cell Res 2012, 318(9):1068-1073. 
121. Babitt JL, Lin HY: Mechanisms of anemia in CKD. J Am Soc Nephrol 2012, 23(10):1631-1634.

122. Chang FC, Chou YH, Chen YT, Lin SL: Novel insights into pericyte-myofibroblast transition and therapeutic targets in renal fibrosis. J Formos Med Assoc 2012, 111(11):589-598.

123. Ward M: Homocysteine, folate, and cardiovascular disease. Int J Vitam Nutr Res 2001, 71(3):173-178.

124. Amini M, Khosravi M, Baradaran HR, Atlasi R: Vitamin B12 supplementation in end stage renal diseases: a systematic review. Med J Islam Repub Iran 2015, 29:167.

125. McMahon GM, Hwang SJ, Tanner RM, Jacques PF, Selhub J, Muntner P, Fox CS: The association between vitamin $\mathrm{B} 12$, albuminuria and reduced kidney function: an observational cohort study. BMC Nephrol 2015, 16:7.

126. Huang W, Shaikh SN, Ganapathy ME, Hopfer U, Leibach FH, Carter AL, Ganapathy V: Carnitine transport and its inhibition by sulfonylureas in human kidney proximal tubular epithelial cells. Biochem Pharmacol 1999, 58(8):1361-1370.

127. Marthaler NP, Visarius T, Kupfer A, Lauterburg BH: Increased urinary losses of carnitine during ifosfamide chemotherapy. Cancer Chemother Pharmacol 1999, 44(2):170-172.

128. Shinozaki Y, Furuichi K, Toyama T, Kitajima S, Hara A, Iwata Y, Sakai N, et al.: Impairment of the carnitine/organic cation transporter 1-ergothioneine axis is mediated by intestinal transporter dysfunction in chronic kidney disease. Kidney Int 2017, 92(6):1356-1369.

129. Ahmad S: L-carnitine in dialysis patients. Semin Dial 2001, 14(3):209-217.

130. Hu FB: Do functional foods have a role in the prevention of cardiovascular disease? Circulation 2011, 124:538-540.

131. Fishman SM, Christian P, West KP: The role of vitamins in the prevention and control of anaemia. Public Health Nutr 2000, 3(2):125-150.

132. Robinson K, Gupta A, Dennis V, Arheart K, Chaudhary D, Green R, Vigo P, et al.: Hyperhomocysteinemia confers an independent increased risk of atherosclerosis in endstage renal disease and is closely linked to plasma folate and pyridoxine concentrations. Circulation 1996, 94(11):2743-2748.

133. Florentin M, Elisaf MS, Rizos CV, Nikolaou V, Bilianou E, Pitsavos C, Liberopoulos EN: L-Carnitine/Simvastatin Reduces Lipoprotein (a) Levels Compared with Simvastatin Monotherapy: A Randomized Double-Blind Placebo-Controlled Study. Lipids 2017, 52(1):1-9.

134. Imagawa S, Tarumoto T, Suzuki N, Mukai HY, Hasegawa Y, Higuchi M, Neichi T, et al.: L-arginine rescues decreased erythropoietin gene expression by stimulating GATA2 with L-NMMA. Kidney Int 2002, 61(2):396-404. 